\title{
PERAN RELIGIUSITAS DALAM PEMBENTUKAN KONSEP DIRI REMAJA
}

\author{
Desi Yustari Muchtar \\ UIN Syarif Hidayatullah Jakarta \\ desi.yustari@uinjkt.ac.id
}

\begin{abstract}
This research wanted to know the effect of religiousity towards teenagers self-concept. Factor analysis of religiousity as predictor of teenagers self-concept was important to see the development of education process in order build the character of nation. It's known that individual who have a positive self-concept always optimist, do new things, to success, not afraid to fail, have self-efficacy, enthusiastic, make a purpose of life, thinking positive, and become a leader that people can rely on. One factor that's very important in self-concept is religion. Experience in religion that obtained by individuals since child can effected their personality when become an adult and be a part of their self-concept. This experience is called religiousity. This research involved 514 junior high school students in Tangerang Selatan. Result showed religiousity gave a significant effect toward teenagers self-concept by 24,7\% (daily experience (14,9\%); forgiving $(3,9 \%)$; private practice $(4,7 \%)$; religion as coping $(0,7 \%))$
\end{abstract}

Keyword: Religiousity, Self-Concept, Teenager

\begin{abstract}
Abstrak
Penelitian ini bertujuan untuk mengetahui pengaruh faktor religiusitas (pengalaman beragama sehari-hari, kebermaknaan hidup dengan beragama, meyakini ajaran agama dan mengekspresikan keagamaan sebagai sebuah nilai, memaafkan, praktek beragama secara pribadi, serta agama sebagai coping) terhadap konsep diri remaja. Analisis faktor religiusitas sebagai prediktor konsep diri remaja sangat penting dilakukan untuk pengembangan proses pendidikan dalam kaitannya membangun karakter bangsa. Salah satu faktor yang memegang peranan penting dalam membentuk konsep diri adalah agama. Pengalaman beragama yang didapatkan oleh seorang anak sejak dini akan mempengaruhi kepribadian yang akan dibawa saat anak tersebut menjadi dewasa dan akan menjadi bagian dari konsep dirinya. Pengalaman keberagamaan dapat disebut juga dengan istilah religiusitas. Penelitian ini melibatkan 514 siswa-siswa SMP di lingkungan Tangerang Selatan. Berdasarkan hasil uji hipotesis, dapat diambil kesimpulan bahwa religiusitas memberikan pengaruh yang signifikan terhadap konsep diri remaja, dengan nilai kontribusi sebesar 24,7\%. Bila dikaji lebih lanjut faktor pengalaman beragama sehari-hari memberikan kontribusi sebesar 14,9\%, memaafkan $3,9 \%$, praktek beragama secara pribadi $4,7 \%$, serta agama sebagai coping memberikan pengaruh $0,7 \%$.
\end{abstract}

Kata Kunci: Konsep Diri, Religiusitas, Remaja

Diterima: 5 April 2015

Direvisi: 8 Mei 2015

Disetujui: 16 Mei 2015 


\section{PENDAHULUAN}

Istilah karakter bukanlah hal baru. Studi tentang karakter telah lama menjadi objek perhatian para psikolog, pedagog, pendidik atau para pakar lainnya. Bahkan Presiden RI Susilo Bambang Yudhoyono pun mencanangkan pentingnya pendidikan karakter. Lebih jauh sebelumnya, mantan presiden RI pertama Bung Karno telah mencanangkan salah satu action plan dari tujuan nasional adalah pembangunan karakter unutk menyongsong masa depan kesiapan manusia Indonesia.

Pada dasarnya, karakteristik remaja cenderung labil, kondisi emosi mudah berubah, serta mudah terpengaruh oleh lingkungan mulai dari perkembangan teknologi hingga relasi sosial. Namun remaja yang dapat mengontrol tingkah lakunya dengan baik sesuai dengan norma yang berlaku, dapat terhindar dari hal-hal yang negatif. Sehingga mereka dapat bersikap luwes dalam masyarakat, mampu menjalankan berbagai perannya dengan tepat sebagai pelajar, sebagai anak, serta sebagai teman. Mereka inilah para remaja yang memiliki konsep diri positif (Mc Candles dalam Garwood, 1976).

Konsep diri memegang peranan yang sangat penting dalam kehidupan remaja. Dengan melihat konsep diri seseorang melalui tingkah lakunya, maka dapat diketahui bahwa orang yang memiliki konsep diri positif akan selalu optimis, berani mencoba hal-hal baru, berani sukses, berani gagal, percaya diri, antusias, merasa diri berharga, berani menetapkan tujuan hidup, bersikap dan berpikir positif, dan dapat menjadi seorang pemimpin yang handal. Sebaliknya, mereka yang konsep dirinya negatif cenderung memiliki rasa tidak percaya diri, tidak berani mencoba hal-hal baru, tidak berani mencoba hal yang menantang, takut gagal, takut sukses, merasa diri bodoh, rendah diri, merasa diri tidak berharga, merasa tidak layak untuk sukses, pesimis, dan masih banyak perilaku inferior lainnya (Gunawan, 2005).

Fitts (dalam Agustiani, 2006) mengemukkan bahwa konsep diri merupakan aspek penting dalam diri seseorang, karena kosep diri seseorang merupakan kerangka acuan ( frame of reference) dalam berinteraksi dengan lingkungan. Fitts juga mengatakan bahwa konsep diri berpengaruh kuat terhadap tingkah laku seseorang. Dengan mengetahui konsep diri seseorang, maka akan lebih mudah meramalkan dan memahami tingkah laku orang tersebut. Pada umumnya tingkah laku individu berkaitan dengan gagasangagasan tentang dirinya sendiri. 
Agustiani (2006) menjelaskan bahwa konsep diri bukan merupakan faktor bawaan, melainkan berkembang dari pengalaman yang terus menerus dan terdiferensiasi. Dasar dari konsep diri individu ditanamkan pada saat-saat dini kehidupan anak dan menjadi dasar yang mempengaruhi tingkah lakunya dikemudian hari. Konsep diri terbentuk melalui proses belajar sejak masa pertumbuhan seorang manusia dari kecil hingga dewasa. Lingkungan, pengalaman dan pola asuh orang tua turut memberikan pengaruh yang signifikan terhadap konsep diri yang terbentuk. Jika lingkungan memberikan sikap yang baik dan positif, maka anak akan merasa dirinya cukup berharga sehingga tumbuhlah konsep diri yang positif (Rini, 2002).

Faktor lain yang juga memegang peranan penting dalam membentuk konsep diri adalah agama. Pengalaman beragama yang didapatkan oleh seorang anak sejak dini akan mempengaruhi kepribadian yang akan dibawa saat anak tersebut menjadi dewasa dan akan menjadi bagian dari konsep dirinya, pengalaman keberagamaan itu akan menjadi penuntun hidupnya ketika berinteraksi dengan teman sebaya ataupun masyarakat sekitar (Daradjat, 1999). Pengalaman keberagamaan dapat disebut juga dengan istilah religiusitas.

Lebih jauh lagi religiusitas dapat diartikan sebagai seberapa jauh pengetahuan, kokohnya keyakinan pelaksanaan ibadah dan kaidah, serta penghayatan atas agama yang dianutnya (Nashori \& Mucharam, 2002). Menurut Fetzer (1999), religiusitas adalah sebarapa kuat individu penganut agama merasakan pengalaman beragama sehari-hari (daily spiritual experience), mengalami kebermaknaan hidup dengan beragama (religious meaning), mengekspresikan keagamaan sebagai sebuah nilai (value), meyakini ajaran agamanya (belief), memaafkan (forgiveness), praktek beragama secara pribadi (private religious practices), agama sebagai coping (religious/spiritual coping), dukungan beragama (religious support), sejarah keberagamaan (religious/ spiritual history), komitmen (commitment), organisasi atau kegiatan keagamaan (organizational religiosness) dan pilihan agama (religious preference).

Dalam penelitian ini tidak semua dimensi religiusitas digunakan, melainkan hanya enam dimensi saja yang digunakan, yaitu dimensi: daily spiritual experience, religious meaning, value \& belief, forgiveness, private religious practices, religious and spiritual coping. Hal ini didasarkan pada karakteristik remaja di Indonesia yang cenderung menjalani keyakinan agamanya yang lebih banyak dipengauhi oleh pilihan beragama orang tuanya. Sehingga dimensi lain dirasa tidak relevan diperhitungkan pada penelitian ini. 
Dari hasil penelitian yang dilakukan oleh Purnama menunjukkan bahwa dimensi-dimensi religiusitas memiliki kontribusi yang besar terhadap konsep diri. Hal senada juga diungkapkan oleh Zakiah (2007) dalam penelitiannya yang berjudul Pengaruh Pendidikan Agama Islam dalam Keluarga terhadap Konsep Diri pada Remaja. Hasil penelitian menunjukkan bahwa terdapat pengaruh positif yang signifikan antara pendidikan agama (islam) dalam keluarga terhadap konsep diri pada remaja. Artinya semakin tinggi pendidikan agama seseorang yang didapatkan dalam keluarga maka akan semakin positif konsep diri seseorang itu, sebaliknya semakin kurangnya pendidikan agama (Islam) yang didapatkan seseorang dalam keluarganya maka konsep dirinya akan cenderung negatif.

Berdasarkan penjabaran di atas, terlihat bahwa pentingnya konsep diri remaja bagi pengembangan karakter bangsa. Salah satu hal yang mempengaruhi konsep diri remaja adalah pengahayatan terhadap nilai-nilai agama, dengan kata lain religiusitas. Selanjutnya peneliti akan menguji asumsi pengaruh religiusitas terhadap konsep diri remaja, dan melihat kontribusi aspek-aspek religiusitas terhadap perkembangan konsep diri remaja.

\section{Konsep Diri}

Calhoun dan Acocella (1990) mendefinisikan konsep diri sebagai pandangan pribadi yang dimiliki seseorang tentang dirinya sendiri.

Selanjutnya, Paik dan Michael (2002) menjelaskan konsep diri sebagai kumpulan keyakinan-keyakinabn yang kita miliki mengenai diri kita sendri dan hubungannya dengan perilaku dalam situasi-situasi tertentu.

Fitts (dalam Agustiani, 2006) mengemukkan bahwa konsep diri merupakan aspek penting dalam diri seseorang, karena kosep diri seseorang merupakan kerangka acuan (frame of reference) dalam berinterksi dengan lingkungan. Fitts juga mengatakan bahwa konsep diri berpengaruh kuat terhadap tingkah laku seseorang. Dengan mengetahui konsep diri seseorang, maka akan lebih mudah meramalkan dan memahami tingkah laku orang tersebut. Pada umumnya tingkah laku individu berkaitan dengan gagasangagasan tentang dirinya sendiri.

Konsep diri memiliki bagian-bagian atau dimensi-dimensi yang saling berinteraksi dan membentuk suatu kesatuan yang utuh, sehingga kita dapat mengatakannya sebagai konsep diri. Fitts ( dalam Agustiani, 2006), membagi konsep diri dalam dua dimensi pokok, yaitu sebagai berikut: 
1. Dimensi internal; Dimensi iternal atau yang disebut juga kerangka acuan internal (internal frame of reference) adalah penilaian yang diakukan individu yakni penilaian yang dilakukan individu terhadap dirinya sendiri berdasarkan dunia didalam dirinya. Dimensi ini terdiri dari tiga bentuk:

a. Diri identitas (identity self); Bagian diri ini merupakan aspek yang paling mendasar pada konsep diri dan mengacu pada pertanyaan, \|siapakah saya\| dalam pertanyaaan tersebut terdapat label-label dan simbol-simbol yang diberikan pada diri (self) oleh individu-individu yang bersangkutan untuk menggambarkan identitasnya dan membangun dirinya.

b. Diri perilaku (behavioral self); Diri pelaku merupakan persepsi individu tentang tingkah lakunya, yang berisikan segala kesadaran mengenai \| apa yang dilakukan oleh diri\|. Selain itu bagian ini berkaitan erat dengan diri identitas.

c. Diri penerimaan / penilai (judging self); Dari penilai berfungsi sebagai pengamat, penentu standar, dan duduknnya adalah sebagai perantara (mediator) antara diri identitas dan diri perilaku.

2. Dimensi eksternal ; Pada dimensi eksternal, individu menilai dirinya melalui hubungan dan aktivitas sosialnya, nili-nilai yang dianutnya, serta hal-hal lain diluar dirinya. Dibedakan menjadi lima bentuk:

a. Diri fisik; Menyangkut persepsi seseorang terhadap keadaan dirinya secara fisik.

b. Diri etik-moral; Bagian ini merupakan persepsi seseorang terhadap dirinya dilihat dari standar pertimbangan nilai moral dan etika.

c. Diri pribadi; Merupakan perasaan atau persepsi seseorang tentang keadan pribadinya.

d. Diri keluarga; Menunjukkan perasaan dan harga diri seorang dalam kedudukannya sebagai anggota keluarga.

e. Diri sosial; Bagian ini merupakan penilaian individu terhadap interaksi dirinya dengan orang lain maupun lingkungan disekitarnya. Seluruh bagian diri ini, baik internal / eksternal saling berinteraksi dan membentuk suatu kesatuan yang utuh untuk menjelaskan hubungan antara dimensi-dimensi internal dan eksternal. 


\section{Konsep Diri Remaja}

Menurut Mc Candles, Konsep diri remaja yang sehat :

\section{Tepat dan Sama}

Konsep diri remaja itu tepat dan sama dengan kenyataan yang ada pada diri remaja itu sendiri. Contoh : seorang remaja laki-laki mampu memerankan dirinya, baik dalam penampilan maupun dalam tugas dan tanggung jawabnya sebagai pria maskulin.

2. Fleksibel

Konsep diri yang sehat ditandai oleh kefleksibelan atau keluawesan remaja dalam menjalankan perannya di masyarakat. Contoh : seorang remaja dapat memainkan perannya sebagai siswa di sekolah dengan konsentrasi belajar, mengerjakan tugas, kerjasama dalam diskusi, disiplin, dsb. Dan dapat memerankan perannya dirumah sebagai anak dan kakak dengan menjaga adiknya, membantu orang tuanya, dsb

3. Kontrol diri

Remaja dengan konsep diri sehat, mampu mengontrol dirinya sendiri sesuai standar bertingkah laku yang telah menjadi miliknya sendiri, bukan diatur oleh keharusan-keharusan orang lain.

\section{Religiusitas}

Kata religiosity (religiusitas/keberagamaan) berasal dari bahasa Latin; religisitas, dan pertama kali ditulis dalam bahasa Inggris pada Abad ke-15. Pengertian awal dari religiusitas ini digunakan untuk mengartikan ungkapan berlebihan atau patologis dari perasaan keberagamaan (Kavros, 2010 dalam David A. Leeming, Kathryn Madden, Stanton Marlan, 2010).

Zinnbauer (2003): - Religiousness can be understood as a personal or group search for the sacred that unfold within a traditional sacred context.

Zinnbauer (2003): - Religiusitas dapat dipahami sebagai suatu pencarian individu atau kelompok pada hal yang sakral yang terbuka pada konteks kesakralan tradisional (dalam Shane J. Lopez, 2003).

Keberagamaan (religiousitas) berasal dari kata agama (religion). Dalam The Cambridge Dictionary of Psychology (2009), secara psikologis agama memiliki arti:

1. Sebagai pencarian spesifik atas kebermaknaan

2. Agama berkonstribusi untuk memperkuat kontrol diri (self-control)

3. Dimotivasi oleh kebutuhan untuk penyatuan, integrasi, dan harmoni

4. Sebagai pemenuhan kebutuhan atas kasih sayang dan dukungan sosial, termasuk juga pembentukan identitas dan jati diri 
5. Mengembangkan dan memperkuat kecenderungan altruistik

Sementara, Peregirine Murphy Kavros (2010), menyatakan bahwa banyak definisi tentang agama telah diusulkan, tetapi satu pendekatan untuk menghindari bias budaya dan ideologi sekular, maka agama mencakup beberapa aspek, yaitu:

1. Doktrin (Ajaran agama)

2. Mitos

3. Etika (aturan/moral)

4. Peribadatan (Ritual)

5. Pengalaman Keberagamaan

6. Institusi sosial (pendidikan atau pelayanan sosial) (dalam David A. Leeming, Kathryn Madden, Stanton Marlan, 2010)

Keberagamaan telah dipertimbangkan sebagai suatu unsur pokok dan positif dalam perkembangan manusia oleh banyak psikolog Amerika pada abad keduapuluh seperti William James, G. Stanley Hall, George Coe, dan Edwin Starbuck. Selama masa ini psikolog Eropa seperti Sigmund Freud dan Carl Gustav Jung juga melahirkan karya yang berpengaruh yang menggambarkan hubungan antara pengalaman beragama dengan penyakit jiwa atau kesehatan mental. (Brian J. Zinnbauer, dalam Shane J. Lopez, 2009).

\section{Dimensi-Dimensi Religiusitas}

Jhon E. Fetzer (2003), menjelaskan dimensi-dimensi religiusitas adalah: Pengalaman beragama sehari-hari (daily spiritual experience), kebermaknaan (meaning), nilai (values), keyakinan (beliefs), pengampunan (forgiveness), praktek beragama secara pribadi (private religious practices), agama sebagai coping (religious/spiritual coping), dukungan beragama (religious support), sejarah keberagamaan (religious/ spiritual history), komitmen (commitment), organisasi atau kegiatan keagamaan (organizational religiosness) dan pilihan agama (religious preference).

1. Pengalaman Beragama Sehari-hari (Daily Spiritual Experience)

Domain ini dimaksudkan untuk mengukur persepsi individu pada hal-hal yang transendental (Tuhan, atau yang bersifat ketuhanan) dalam kehidupan sehari-hari, dan persepsi dalam keterlibatan hal yang transendental dalam hidup.

2. Kebermaknaan (Meaning) 
Membangun kebermaknaan atas kejadian dalam hidup adalah usaha yang penting bagi manusia. Mengukur pencarian inidividu atas makna (proses) dan berhasil atau gagal atas upaya pencarian tersebut (hasil). Usaha untuk mengukur kontruk kebermaknaan, secara luas mengacu pada kerangka teori Victor Frankl yang menyatakan bahwa - kehendak untuk hidup (will to meaning) $\|$ adalah karakteristik manusia yang paling utama, dan yang dapat menyebabkan gangguan mental/fisik adalah tidak tercapainya makna hidup (Frankl, 1963).

3. Nilai (Value)

Domain ini dimaksudkan untuk mengukur dimensi-dimensi yang berbeda dari nilai yang ditempatkan individu pada agama (Seberapa penting agama dalam hidupmu?\|), yang tercakup pada domain yang disebut sebagai — komitmen\|. Domain ini bukan tentang ada tidaknya nilai dalam diri individu, tetapi bagaimana tiap individu menilai sesuatu. Domain ini didasarkan pada teori Merton (1968), yang menggambarkan nilai sebagai tujuan dan norma-norma sarana dalam mencapai tujuan tersebut.

4. Keyakinan (Belief)

Ciri-ciri utama keberagamaan adalah domain kognitif atas keyakinan; anggota pada suatu kelompok beragama disebut sebagai — penganut $\|$.

Bagaimanapun para penganut agama sangat beragam dalam memegang keyakinan mereka, mungkin mereka setuju atau tidak setuju dengan keyakinan yang seharusnya mereka yakini.

5. Pengampunan (Forgiveness)

Domain ini mencakup 5 dimensi pengampunan: Pengakuan, merasa diampuni Tuhan, merasa diampuni oleh orang lain, memaafkan orang lain, memaafkan diri sendiri. Kaplan et al (1993) dan Enright (1992), mencatat bahwa konsep pengampunan/ memaafkan sedikit banyak terdapat pada ajaran Islam, Zen Budha dan Konfusianis. Menurut Kaplan, kita membutuhkan kajian lintas budaya untuk mengkaji konsep memaafkan ini.

6. Praktek Beragama Secara Pribadi (Private Religious Practices)

Praktek beragama secara pribadi menggambarkan suatu perilaku yang mendasari konstruk yang lebih luas dari keterlibatan individu dalam beragama. Domain ini berbeda dengan perilaku beragama dalam domain publik (seperti, dalam organisasi agama, formal atau terlembaga). Praktek keberagamaan secara pribadi tidak terjadi secara terorganisasi, melainkan diluar konteks keberagamaan yang 
teroganisasi. Yaitu bersifat informal, tidak terjadi pada waktu atau tempat tertentu yang sudah dipastikan. Dan biasanya terjadi di rumah secara individual atau bersama keluarga, tidak secara kolektif dan formal. Domain ini mencakup: (1). Dapat diaplikasikan secara luas,

(2). Mengukur perilaku yang lazim/umum dilakukan secara pribadi (private); dan (3). Menggunakan pengukuran psikometri; dan (4). Terdiri dari setidaknya empat item.

7. Agama Sebagai Coping (Religious/Spiritual Coping)

Item dalam domain ini mengukur dua pola agama sebagai coping, yaitu gambaran coping beragama secara positif dengan memahami metode beragama secara baik dan menguasai kondisi stress yang dalam hidup, dan gambaran coping beragama secara negatif dalam usaha menjadikan agama sebagai coping. Domain ini dibangun atas kerangka bahwa terdapat hubungan yang nyata antara kejadian stress dengan berbagai bentuk keterlibatan keberagamaan. (Bearon and Koeing 1990, Bjorck and Cohen 1993, Ellison and Taylor 1996, Lindenthal et al 1970)

8. Dukungan Beragama (Religious Support)

Item dalam domain ini didisain untuk mengukur aspek tertentu dari hubungan sosial antara partisipan dalam beribadah dimana mereka saling berbagi dan memberikan dukungan.

9. Sejarah Keberagamaan (Religious/Spiritual History)

Domain ini mengukur sejarah keberagamaan tiap individu. Sebagai perbandingan untuk mengukur parisipasi keberagamaan mereka saat ini. Item dalam domain ini menyediakan pengukuran singkat dari partisipasi keberagamaan sepanjang rentang kehidupan.

10. Komitmen (Commitment)

Item dalam domain ini didisain untuk mengukur urgensi komitmen individu dalam memegang keyakinan mereka dalam beragama

11. Organisasi atau Kegiatan Keagamaan (Organizational Religiosness)

Domain ini mengukur keterlibatan individu dalam institusi beragama pada ruang publik yang formal seperti masjid, gereja, pura dsb. Domain ini mencakup dimensi perilaku dan sikap.

12. Pilihan Beragama (Religious Preference)

Item ini didisain untuk mengetahui pilihan individu dalam beragama yang teridentifikasi. Item dalam domain ini secara umum melakukan identifikasi dan pendekatan pada suatu tradisi atau organisasi keagamaan. Jadi, ungkapan dalam pemilihan beragama mungkin 
ditunjukkan dengan menjadi anggota pada kegiatan keagamaan, atau sebagai partisipan.

\section{Remaja}

Istilah remaja atau adolescence, seperti yang digunakan saat ini, mempunyai arti yang lebih luas, mencakup kematangan mental, emosional, sosial, dan fisik (Hurlock, 1980). Remaja berkembang dalam beberapa tahapan. Remaja awal dimulai pertama kali dengan perubahan fisik atau puberitas yang terjadi pada awal usia 10 tahun, namun secara umum terjadi antara usia 12 sampai 14 tahun. Remaja pada usia pertengahan terjadi kira-kira pada usia 14 sampai 16-17 tahun, lalu remaja akhir terjadi pada rentang usia 17-20 tahun. Masa peralihan dari SD ke SMP adalah periode kecemasan bagi banyak anak-anak karena mereka menghadapi kehidupan dan pengalaman sosial yang berbeda; perubahan fisik, biologis, kognitif dan emosional yang menjadi sumber stres (Guindon, 2010).

Sementara menurut Erik Erikson (2002), remaja adalah tahap perkembangan kelima, yang disebut sebagai tahap —identity versus identity confusion $\|$ yang berlangsung antara usia 10-20 tahun. Pada masa ini individu dihadapkan dengan penemuan tentang siapa mereka, bagaimana mereka nantinya dan ke mana mereka menuju dalam kehidupannya. Anak remaja dihadapkan pada banyak peran baru dan status sebagai orang dewasa- pekerjaan dan romantis misalnya. Orang tua harus mengizinkan anak remaja menjelejahi banyak peran dan jalan yang berbeda dalam suatu peran khusus. Jika anak remaja menjajaki peranperan semacam itu dengan cara sehat dan tiba pada suatu jalan yang positif untuk diikuti dalam kehidupan, maka identitias yang positif akan dicapai. Tetapi jika suatu identitas remaja ditolakkan oleh orang tua, atau remaja tidak secara memadai menjajaki banyak peran serta jika jalan masa depan yang positif tidak dijelaskan, maka kebingungan identitas merajalela (Santrock, 2002).

\section{METODE}

Populasi dalam penelitian ini adalah remaja berusia 14-16 tahun yang berada di lingkungan Tangerang Selatan. Sampel berjumlah 514 orang. Metode penumpulan data menggunakan skala Konsep Diri TSCS yang sudah diadaptasi menjadi 20 item dan skala Religiusitas dari Fetzer yang berjumlah 35 item. Tahap awal penelitian ini dimulai dengan memvalidasi 
alat ukur dengan metode CFA. Setelah mendapatkan item yang valid, data diolah dengan teknik analisis regresi.

\section{HASIL}

Tabel 1

Hasil Regresi IV terhadap DV

\begin{tabular}{llllll}
\hline Model & Sum of Squares & Df & Mean Square & F & Sig. \\
\hline $1 \quad$ Regression & 12668.590 & 6 & 2111.432 & 27.711 & $.000^{\mathrm{a}}$ \\
$\quad$ Residual & 38631.410 & 507 & 76.196 & & \\
$\quad$ Total & 51300.000 & 513 & & & \\
\hline
\end{tabular}

Keterangan:

a. Predictors: (Constant), FRaSC, FFOR, FPRP, FMEAN, FVB, FDSE

b. Dependent Variable: FSC

Berdasarkan tabel di atas, maka Hipotesis yang menyatakan ada pengaruh yang signifikan dimensi religiusitas (daily spiritual experience, religious meaning, value \& belief, forgiveness, private religious practices, religious and spiritual coping) terhadap konsep diri diterima.

Penelitian ini sejalan dengan penelitian yang telah dilakukan oleh Purnama (2012) bahwa aspek religiusitas memberikan kontribusi terhadap konsep diri. Bahwa dalam membentuk konsep diri yang positif pada remaja diperlukan aspek-aspek religiusitas.

Tabel 2

Kontribusi IV terhadap DV

\begin{tabular}{|c|c|c|c|c|c|c|c|c|}
\hline \multirow[b]{2}{*}{ Model } & \multirow[b]{2}{*}{$\mathbf{R}$} & \multirow[b]{2}{*}{$\begin{array}{c}\text { R } \\
\text { Square }\end{array}$} & \multirow[b]{2}{*}{$\begin{array}{l}\text { Adjusted } \\
\text { R Square }\end{array}$} & \multirow[b]{2}{*}{$\begin{array}{l}\text { Std. Error } \\
\text { of the } \\
\text { Estimate }\end{array}$} & \multicolumn{4}{|c|}{ Change Statistics } \\
\hline & & & & & $\begin{array}{c}\mathbf{R} \\
\text { Square } \\
\text { Change }\end{array}$ & $\begin{array}{c}\text { F } \\
\text { Change }\end{array}$ & df1 df2 & $\begin{array}{c}\text { Sig. F } \\
\text { Change }\end{array}$ \\
\hline 1 & $.497^{\mathrm{a}}$ & .247 & .238 & 8.72904 & .247 & $27.711 \quad 6$ & 50 & 7.000 \\
\hline
\end{tabular}

Keterangan:

a. Predictors: (Constant), FRaSC, FFOR, FPRP, FMEAN, FVB, FDSE

Berdasarkan tabel di atas dapat dilihat bahwa perolehan R square sebesar 0.247. Ini artinya bahwa dimensi-dimensi religiusitas (daily spiritual experience, religious meaning, value \& belief, forgiveness, private religious practices, religious and spiritual coping) memberikan sumbangsih sebesar $24.7 \%$ 
terhadap konsep diri remaja. Sedangkan $75.3 \%$ sisanya dipengaruhi oleh variabel lain diluar penelitian ini.

Hal ini sejalan dengan penelitian yang dilakukan oleh Rini (2002) bahwa konsep diri sifatnya dinamis dan dipengaruhi oleh berbagai macam faktor seperti agama, pengalaman yang diperoleh, pengasuhan orangtua dan perlakuan lingkungan terhadap diri seseorang. Namun religiusitas yang memberikan konstribusi sebesar hampir $25 \%$ menandakan bahwa penanaman nilai agama merupakan faktor yang sangat penting dalam pengasuhan anak.

Tabel 3

Koefisien Regresi

\begin{tabular}{|c|c|c|c|c|c|c|c|c|}
\hline & \multirow{2}{*}{ Model } & \multicolumn{2}{|c|}{$\begin{array}{l}\text { Unstandardized } \\
\text { Coefficients }\end{array}$} & \multirow{2}{*}{$\begin{array}{c}\text { Standardized } \\
\text { Coefficients } \\
\text { Beta }\end{array}$} & \multirow{2}{*}{$\mathbf{t}$} & \multirow{2}{*}{ Sig. } & \multicolumn{2}{|c|}{$\begin{array}{l}95.0 \% \text { Confidence } \\
\text { Interval for B }\end{array}$} \\
\hline & & B & $\begin{array}{c}\text { Std. } \\
\text { Error }\end{array}$ & & & & $\begin{array}{l}\text { Lower } \\
\text { Bound }\end{array}$ & $\begin{array}{l}\text { Upper } \\
\text { Bound }\end{array}$ \\
\hline \multirow[t]{7}{*}{1} & (Constant) & 15.235 & 2.881 & & 5.288 & .000 & 9.575 & 20.895 \\
\hline & FDSE & .148 & .059 & .148 & 2.492 & .013 & .031 & .264 \\
\hline & FMEAN & .041 & .047 & .041 & .881 & .379 & -.051 & .133 \\
\hline & FVB & -.027 & .052 & -.027 & -.528 & .598 & -.130 & .075 \\
\hline & FFOR & .185 & .042 & .185 & 4.397 & .000 & .102 & .267 \\
\hline & FPRP & .235 & .043 & .235 & 5.493 & .000 & .151 & .319 \\
\hline & FRaSC & .114 & .051 & .114 & 2.245 & .025 & .014 & .214 \\
\hline
\end{tabular}

Keterangan:

a. Dependent Variable: FSC

Berdasarkan tabel diatas, maka persamaan regresi penelitian ini sebagai berikut:

Konsep Diri Remaja $=15.235+0.148$ daily spiritual experience +0.041 religious meaning -0.027 value \& belief +0.185 forgiveness +0.235 private religious practices +0.114 religious and spiritual coping.

Dari persamaan di atas terdapat empat koefisien yang signifikan dan memiliki hubungan yang positif terhadap konsep diri remaja, yaitu dimensi: daily spiritual experience, forgiveness, private religious practices, religious and spiritual coping. Sedangkan sisa variabel lainnya tidak signifikan. 
Untuk meningkatkan konsep diri remaja yang positif maka remaja perlu meningkatkan ritual ibadah sehari-hari, memaknai Tuhan maha pengampun sehingga terhindar dari rasa dendam dengan memaafkan orang lain, dan saat berada dalam masalah hendaknya menggunakan pendekatan agama sebagai solusi pemecahan masalah.

\section{Tabel 4}

Proporsi Varians IV terhadap DV

\begin{tabular}{|c|c|c|c|c|c|c|c|c|c|}
\hline \multirow[t]{2}{*}{ Model } & \multirow[t]{2}{*}{$\mathbf{R}$} & \multirow{2}{*}{$\begin{array}{c}\text { R } \\
\text { Square }\end{array}$} & \multirow{2}{*}{$\begin{array}{l}\text { Adjusted } \\
\text { R Square }\end{array}$} & \multirow{2}{*}{$\begin{array}{l}\text { Std. Error of } \\
\text { the Estimate }\end{array}$} & \multicolumn{5}{|c|}{ Change Statistics } \\
\hline & & & & & $\begin{array}{c}\text { R Square } \\
\text { Change }\end{array}$ & $\begin{array}{c}\text { F } \\
\text { Change }\end{array}$ & df1 & df2 & $\begin{array}{c}\text { Sig. F } \\
\text { Change }\end{array}$ \\
\hline 1 & $.386^{\mathrm{a}}$ & .149 & .147 & 9.23606 & .149 & 89.373 & 1 & 512 & .000 \\
\hline 2 & $.391^{\mathrm{b}}$ & .153 & .150 & 9.22128 & .004 & 2.643 & 1 & 511 & .105 \\
\hline 3 & $.392^{\mathrm{c}}$ & .154 & .149 & 9.22641 & .001 & .431 & 1 & 510 & .512 \\
\hline 4 & $.439^{\mathrm{d}}$ & .193 & .187 & 9.01883 & .039 & 24.748 & 1 & 509 & .000 \\
\hline 5 & $.489^{\mathrm{e}}$ & .239 & .232 & 8.76370 & .047 & 31.068 & 1 & 508 & .000 \\
\hline 6 & $.497^{\mathrm{f}}$ & .247 & .238 & 8.72904 & .007 & 5.042 & 1 & 507 & .025 \\
\hline
\end{tabular}

Keterangan:

a. Predictors: (Constant), FDSE

b. Predictors: (Constant), FDSE, FMEAN

c. Predictors: (Constant), FDSE, FMEAN, FVB

d. Predictors: (Constant), FDSE, FMEAN, FVB, FFOR

e. Predictors: (Constant), FDSE, FMEAN, FVB, FFOR, FPRP

f. Predictors: (Constant), FDSE, FMEAN, FVB, FFOR, FPRP, FRaSC

Berdasarkan tabel di atas dapat diketahui bahwa terdapat empat dimensi yang memberikan kontribusi yang signifikan terhadap konsep diri, yaitu dimensi: daily spiritual experience sebesar 14.9\%, forgiveness sebesar 3.9\%, private religious practices sebesar $4.7 \%$ serta religious and spiritual coping sebesar $0.7 \%$.

Kondisi emosi remaja yang cenderung labil dapat diseimbangkan dengan meningkatkan ritual ibadah sehari-hari yang lebih intens. Semakin remaja melakukan ibadah, maka emosinya akan menjadi tenang dan mereka memiliki landasan dalam berperilaku dan bertindak. Dengan mengontrol dirinya sendiri sesuai standar bertingkah laku, maka konsep dirinya akan semakin sehat (McCandles, ). Walaupun kontribusi coping dengan pendekatan religius hanya memberikan kontribusi sebesar $0,7 \%$, nmaun hal tersebut tetap diperlukan dalam pembentukan konsep diri yang positif. Terkadang remaja melakukan pemecahan masalah dengan cara-cara yang negatif seperti menggunakan narkoba, alkohol, obat terlarang, seks 